\title{
9. Using poetry to capture the Aboriginal voice in oral history transcripts
}

\section{LORINA BARKER}

This paper is a part of an ongoing research project I have been involved with since commencing my $\mathrm{PhD}$ at the University of New England. My interest in the documentation of oral histories, in particular my own community of Weilmoringle, ${ }^{1}$ has been the main focus of my concerns since becoming an early career academic in 2004. Although I left my community several years ago, I continue to hold a strong (and in some ways complex) connection to my traditional country and the people who come from there. Most of the participants I refer to in this paper are Aboriginal members of the community, although I hope to involve non-Aboriginal people from Weilmoringle in the future.

I began recording the stories of members of my community in Weilmoringle in 2005. For the purposes of this paper, the community is both the research participant and the main intended audience for my research, and the core research method and source is oral history. My reason for conducting oral histories is that I believe Aboriginal histories and oral histories are intrinsically linked and for the most part have been largely ignored, misinterpreted or deemed as 'mythical' unreliable sources of knowledge by more traditionally text-based historians.

In using oral histories, I am tapping into the millennia long tradition of oral storytelling as the way that Aboriginal people's history and cultural knowledge has and continues to be conveyed. My dilemma is that I intend to convert these oral and aural experiences into print as a key way to communicate with wider audiences the memories and stories shared with me. Embedded in this conversion is the need to get the text versions of my recordings right. My research participants are speakers of Aboriginal English and it is crucial that the written versions of the oral narratives read and sound like how the participants speak. It is also crucial that the orality of the interviews and the importance of

1 Weilmoringle is an Aboriginal community and sheep station about one hour's drive north-east of Bourke. 
oral history both as a form of memory and as a form of history are conveyed through the words on pages. Finally, it is important that the processes involved in consulting, interviewing, recording, transcribing and presenting are ethical and transparent.

I have written elsewhere about some of the challenges confronting Aboriginal researchers who choose to conduct fieldwork/ research in their own community and with members of their family: the experience can be a frustrating, enjoyable and burdensome undertaking that requires the juggling of multiple, complex, overlapping and at times conflicting roles and responsibilities. ${ }^{2}$ Here I focus on the challenges involved in converting the layered richness, sounds, silences and interactions of the memories recorded through an oral history interview into text. At one level, it is about transcription and editing; at another level, it is about capturing and conveying individuals' memories and stories and the ways in which those shared experiences - including my part in the sharing - become a powerful means to present Indigenous histories in ways that resonate with, and are accessible to, the owners of those histories.

Transcription is often described in the literature as a tedious and time-consuming process, one that is plagued with technical questions of what to include and exclude, as well as the problem of transforming the aural into written text. This paper considers these issues in relation to the accessibility of a transcript to the intended audience, in this case the research participants. I begin by reflecting on my personal experiences of the transcription process and some of the problems I encountered with both the recorded and transcribed versions. Concerned about my initial reactions, I began analysing my own responses and contemplated the effects and implications for the participants in my research. How would they react to a verbatim transcript? Would they feel threatened, embarrassed or upset? If so, how would they want their stories conveyed? How do I make the written word non-threatening and at the same time produce an accurate account of the recorded conversations? What are the alternatives? With these questions in mind, I looked at scholarly arguments that both support and oppose transcription. I sought alternative strategies used by other scholars to convert the voice into printed form. In my search for alternative styles, I discovered free verse poetry. This style is used for the purpose of re-creating in written form the emotion and movement of words as they are spoken and received in conversation, as well as to re-capture the imagery of the interview, and what took place: the interaction between interviewer and participant. Free verse poetry is also used to preserve the traditional practice of oral history storytelling and to create a text version that conveys participant's lived experiences and history. 


\section{The words of a transcript}

Before embarking on my own research project, I had experienced interviews and transcripts as an interviewee. As a result, I had become more aware of the sound of my own voice and how my words looked in print. I had mixed reactions to the recorded and transcribed versions. As a result of these experiences, I am now endeavouring to make my research transcripts less intimidating and more accessible for my research participants. The personal accounts that follow are filled with mixed reactions - surprise, anxiety and amusement, and explain my approach to transcription.

As an undergraduate student I was a participant in and subject of a number of research projects. I was first introduced to the recorded narrative by linguist Diana Eades, who recorded a conversation between my cousin Karen Johnson and myself. The purpose of this recording was to demonstrate our use of English, what is known as Aboriginal English. My memory of this experience is a combination of nerves and excitement at being recorded, coupled with the cold sterile environment of a recording studio. A few months after the recording I received a letter from Eades explaining the accompanying audiotape and booklet entitled, 'The English Language: Past, Present and Future Study Guide $3^{\prime}{ }^{3}$ I skimmed through the booklet to the section containing my conversation with Karen, and was shocked at what I read and heard: strange and silly words on paper and the voice on tape were not like how I thought I spoke. Embarrassed, I packed the tape and booklet away.

A few years later, as a postgraduate student I was approached by a PhD student interested in documenting the experiences of Aboriginal postgraduate students. I agreed to participate in the research, which included several interviews. Some months later, I received the first of many verbatim transcripts. After reading the covering letter, I would scan two or three pages, before becoming bored with the material and I would pack it away. This was how I reacted to each and every transcript, and to be honest I was relieved when they finally ceased. In hindsight, I had willingly given my story, but providing feedback was another issue. The sheer volume made the task seem too time-consuming, especially when I had my own research to contend with. I was uninterested, and oblivious to how important my feedback may have been to the student's research. I had trusted the student researcher enough to share my educational experiences and to portray my story in an ethical and responsible manner, 'to do the right thing by [me] and not make [me] look ignorant' or silly. ${ }^{4}$ But I did not want to read, let alone comment on, the transcripts of our interviews.

3 Eades 1996: 31-32.

4 Brehaut 1999: 29. 
More recently, I read a copy of a transcript that Margaret Somerville (my PhD Co-supervisor) had transcribed from the recorded interview she had conducted with me. Scanning the transcript I soon realised how foreign the verbatim transcript seemed. Given that I found it difficult to read and understand, I also considered the effect and implications for the participants in my research. As I read through the transcript, my initial reaction was one of surprised shock and I was somewhat unsettled at my reaction. The written word seemed so strange. It did not look or read like how I think I speak, instead it looked and read like a foreign language. I thought to myself, 'do I speak like this; gosh I use a lot of ums', 'my words look silly and a little funny'. I was also a little concerned and curious about how I may have been perceived by the transcribers: What did they think of my words? Do they think I made sense? Did they think I knew what I was talking about? Horrified, I packed the transcript away. In retrospect, I had read through the transcript trying to feel the words, to hear the conversation, but what I received in return was merely black ink on white paper, words devoid of emotion and foreign to the eye. These were not my stories and my memories.

\section{Listening to the recordings}

My reservations about the verbatim transcript resurfaced when I began listening to my Weilmoringle recordings in preparation for transcription. Despite my earlier experiences I was not prepared for the shock and amusement of hearing my own voice being thrown back at me through the audio-speakers. I thought, 'My voice doesn't sound like me, it sounds like how my cousin Pattie speaks'. I began to laugh at my voice and immediately stopped the tape and told myself, 'I can't do this. It sounds too weird'. After regaining some composure, I pressed play and re-listened to the recording. 'Why does my voice sound so weird? Why am I laughing? This is serious stuff!' I wondered and chastised myself. I am not laughing at Uncle William's voice, he sounds the same. I'm not laughing at the stories he's telling me. I'm laughing at myself, because it doesn't sound like me, it sounds like my cousin Pattie! Was it Pattie or I who had conducted the interview, I asked myself, smiling as the thought entered my mind. Maybe I should record both our voices, to see how similar they really are. 'Yeah maybe I will' I said to myself as I ejected the tape and put it back in the filing cabinet. 'I can't handle my voice today, so I'll try again another day', I said in an attempt to convince myself.

\section{Writing my voice back into the transcript}

The result of my discomfort at the sound of my own voice was that, initially, when I did start transcribing I found myself writing my voice out of the 
transcript. I typed the words the way I write and not the way I speak. For example, 'there' instead of 'dere', 'you' instead of 'yah', 'used to' instead of 'use-tah'. After realising what I was doing, I quickly rewound the tape and listened more carefully to my pronunciations, until I was convinced that I had understood my own speech mannerism and changed each word accordingly. I discussed the problem with Margaret Somerville and she identified some possible reasons: it highlights the multiple, interrelated and overlapping nature of the roles that I have chosen to undertake as a community person, family member and researcher. More importantly, as a child I learnt how to speak and write in standard Australian English, and if and when I spoke or wrote in Aboriginal English, I was immediately corrected. While I try to incorporate and stay 'true' to each participant's voice, speech mannerism and idiosyncrasies, at the same time I face the problem of how to incorporate my own voice. It is through the process of transcribing that I am relearning how to listen to and write my voice back into the transcript.

All of these experiences both recorded and transcribed versions, were of much concern, and forced me to analyse my own reactions and to contemplate the effects and implications for participants. As a consequence, I searched the literature for arguments that both supported and opposed verbatim transcription, as well as to find alternative strategies used by scholars to convert the voice and the memories conveyed into printed form.

\section{Getting the voice off tape onto page}

I naïvely made the decision to fully transcribe each recording, long before I ventured out into the field, well before I considered or fully understood the enormity of the task I had set myself. Returning from the first field trip, I was determined to follow through with my earlier decision to fully transcribe. As I began transcribing I made the decision to transcribe each recording myself and to include every utterance, pause and background noise. The aim was to transport myself as interviewer and researcher back to the place and time of the interview in order to analyse and to deduce meaning. As Elizabeth Wright argues, 'the best person to prepare the transcript is the interviewer because he/ she was present at the interview'. She adds, '[d]oing your own transcribing is beneficial because you can edit in your own style as you go along and it gives you the opportunity to review the complete interview' ${ }^{5}$

I was seeking my 'style' of transcribing and, in order to develop it, I became interested in how other scholars were transcribing and what methods they were using to convert verbatim transcripts into other forms of text. Rebecca Jones

5 Wright 2005: 57 
explained, '[t]here is no definitive formula for creating a written [transcript] from oral interviews'. ${ }^{6}$ Rather, there are many different approaches and styles of transcribing and presenting speech into written form. The employment of a particular style may depend on a number of contributing factors: the project, the researcher's disciplinary background and the intended audience. Jones further adds that 'different project[s] may require different decisions to be made'. ${ }^{7}$ Wendy Lowenstein was a firm believer that 'Oral history in print should be a "good read"'. At the same time she adds that the interviewer needs to keep in mind and avoid 'doing violence to the informant's story and content' ${ }^{8}$ Elizabeth Wright agrees that producing a 'readable written/printed document from spoken material' is important and should be done by 'using as closely as possible the narrator's words, [and] most importantly [reflect] the intent and meaning of the narrator' ${ }^{9}$ By contrast, Kate Moore is not interested in making the transcript readable. Instead she advocates vehemently for the inclusion of every utterance, which she believes to be 'valuable communicative evidence' that can be analysed and dissected for meaning. ${ }^{10}$ Rosemary Block disagrees, saying that the inclusion of every word and sound does not 'add materially to the text', but instead creates unnecessary interruptions that should be omitted. ${ }^{11}$ Francis Good reminds us that the printed version 'cannot adequately capture the music of speech', what Barry York calls its 'special charm'. ${ }^{12}$ Good explains that as oral history researchers 'we must learn to live with the fact that transcription of the spoken word is more of an art than an exact science'.$^{13}$

\section{Poetically speaking: free verse poetry}

Free verse is a poetic form and an alternative strategy, used by a number of scholars as a tool to convert voice into print. I have followed Rosemary Block, Daphne Patai, Krista Woodley, Loreen Brehaut and Katharine Elise Perry's suggestions on the use of this method. I have also tried to transcribe the recorded interview as accurately as possible in an attempt to capture both the participants' and interviewer's voices and their idiosyncratic ways of communicating. The main purpose for using free verse is to ensure that the written versions of the interviews are more accessible to the participants and that they capture the rhythm and tone of their shared memories.

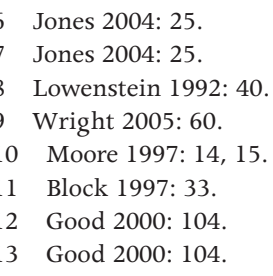


In seeking a form in which to present the interviews, I was inspired to experiment with free verse after reading Rosemary Block's article 'Voiceprint: From Tape to Page: Keeping Faith with the Voice', in which she experimented with free verse in an attempt to 'translate [the] liveliness to the page', and the 'colour, tone and emotion of the voice'. ${ }^{14}$ Daphne Patai also wanted to maintain the essence of the informant's spoken words and used free verse to 'retain the meaning, tone, style and flavor of the original'. ${ }^{15}$ Krista Woodley explained that her use of the poetic form to transcribe oral history interviews was to assist her in the 'analysis of the recording' as well as to 'help [her] data to sing' ${ }^{16}$ In contrast, Loreen Brehaut admits to using free verse as a direct result of her own anxiety over the presentation of an authentic and 'honest' narrative, ${ }^{17}$ and Katharine Elise Perry utilised the poetic form to preserve her mother 'Ethel's voice' and for its 'musical qualities' ${ }^{18} \mathrm{I}$, on the other hand, have employed free verse in my research primarily for the benefit of the core audience, the participants and like Perry I too intend to preserve the participants' voices so that other 'family members [are able to see and] hear [the person] as they read them' ${ }^{19}$

\section{The nature of free verse}

After submitting my first draft of this paper for comment to my supervisor, Janis Wilton and receiving her pencilled remarks, I realised I had not adequately defined free verse. Janis was particularly concerned 'as to why some of the interview materials transformed into poetry and others into free verse or indeed what distinguished the two'. ${ }^{20}$ Admittedly, I was unsure about the difference. Now I was more confused, though pleased that Janis suggested I leave it for now and focus my attention elsewhere.

With the transcription models before me I experimented intuitively with some of my own interviews, but on being questioned about what I meant by free verse, I sought advice from a friend and colleague, Jane O'Sullivan, a Senior Lecturer in the School of Arts at the University of New England. A few weeks later I bumped into Jane and I briefly explained how I was experimenting with the verbatim transcripts and converting them into poetic form. Jane was very interested in my approach and offered to look at my work. A few days later we met for coffee and I took a few of my converted poems for Jane to give me her professional opinion. Jane also explained the functions of free verse poetry: 'it does not have regular metre (metrical structure) and does not have rhyming

14 Block 1995: 65.

15 Patai 1988: 17.

16 Woodley 2004: 49.

17 Brehaut 1999: 30.

18 Perry 2005: 1.

19 Perry 2005: 1

20 Janis Wilton, pers comm, October 2006. 
lines. So it is "free" from the conventions of particular poetical forms such as ballads and sonnets' ${ }^{21}$ Jane also directed me to the work of Dennis Tedlock and Gerard Manley Hopkins. In my search for a simplified explanation of free verse I also turned to the literature. Tom Furniss and Michael Bath explain, free verse 'does not conform to any metrical pattern' ${ }^{22}$ They also assert that the exclusion of rhyme does not necessarily deem it to be free verse. ${ }^{23}$ Nevertheless, they do acknowledge that 'it ... uses line divisions which shape the rhythms of the language for specific ends' ${ }^{24}$ They add that free verse or vers libre ${ }^{25}$ allow [s] poets to take ... radical liberties' in their writings. ${ }^{26}$ This explains the unconventional characteristics that are common in free verse poetry: 'there is no punctuation, the shape is how it is punctuated; the image is echoed; there is music to a line' ${ }^{27}$ What I realised was particularly appealing about the use of free verse for my purpose was that it breaks with grammar and it does not force oral speech patterns into written prose. More importantly, it does not make the research participants' words look 'inferior', ungrammatical and unpunctuated.

\section{From voice to free verse: one, two, three steps}

At first glance, a transcript written in Standard Australian English might seem to be clearer and easier to understand, and it is certainly considered the most acceptable form for an archival document. ${ }^{28}$ But, for the Aboriginal participants in my research, the verbatim transcript is not the only, or the most appropriate, form of converting the recorded interview to print form. Free verse is used as an alternative in an attempt to retain the speech mannerisms: the 'rhythm and rhetorical style', tone and accents of the speaker. ${ }^{29}$ Also, within the context of this research the utilisation of free verse is intended to be less intimidating than a verbatim transcript.

My style of converting voice into free verse is a three-step process. Firstly, I fully transcribe each recording into a verbatim transcript and at the same time, make separate transcription notes about the interview. Secondly, I copy the completed verbatim transcript into another document and begin conversion, by taking out all of my questions and responses. I then arrange the narrator's words on the page by using lines and space to convey the narrator's speech mannerisms: when they have paused, have gone silent or have changed topics.

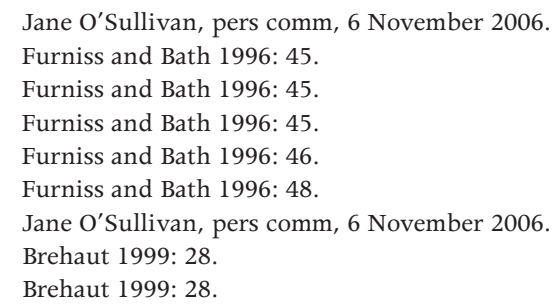


This step is what I call the unedited free verse. It is important to mention that while I do not edit the narrator's voice I do however, edit my voice so as not to interfere with the flow of the narrator's story. Nevertheless, my questions will appear in the text as background information to the free verse extracts. In the final step, the edited free verse, I make some minor editorial changes by omitting the narrator's false starts and repetition.

As mentioned before, I have chosen to fully transcribe, in the style suggested by Kate Moore to include the pauses, false-starts, hesitations (um, arh), repetitions (I mean to say, after all, and the) and the interviewer's verbal encouragements known as back-channelling (yeah, Mhm, uh-huh). ${ }^{30}$ Also included are the 'natural speech patterns' ${ }^{31}$ and 'dialect words [and] phrases' ${ }^{\prime 2}$ as well as the 'phonetic spellings to suggest the sound of the dialect' ${ }^{\prime 3}$ such as 'dere' and 'usetah' and alongside them and enclosed in brackets are the meanings and English spellings 'there', 'used to'. Raphael Samuel suggested that this allows the reader to obtain a 'sense of the personal and individual' and it makes the story come alive. ${ }^{34}$ I have also identified background noises by naming the sound in brackets placed at the end of the sentence. At times, when a word is not clear in the recording, I have added a word or a question mark to indicate my uncertainty. Rosemary Block points out that while the 'Transcript may not ... be essential for access [by participants], ... it is necessary for publication and perhaps for preservation purposes' ${ }^{35}$ While the participant will receive a copy of their verbatim transcript along with a copy of the audio recording and free verse poetry, the main purpose of the transcript is for archival deposit, which can then be accessed by other researchers who can infer their own interpretations of the recording.

As a guide, I have used Block, Patai, Brehaut, Woodley and O'Sullivan's suggestions for converting the voice into print. The following narratives are extracts from the original verbatim transcript that have been converted into free verse to demonstrate the utilisation of this method as a possible solution for ensuring the transcript and its contents are accessible to my research participants. Example one illustrates the process of converting the verbatim transcript into an edited free verse. Example two captures the rhythm of speech, and example three is an annotated free verse that aids my analysis of the recording.

\footnotetext{
Moore 1997: 17.

Block 1997: 33.

Samuel 1998: 390.

Samuel 1998: 391.

Samuel 1998: 390.

Block 1997: 33.
} 


\section{Example one: verbatim transcript to edited free verse}

The following example is my initial attempt at converting voice into print. The aim was to convey to the reader a sense of the narrator's voice telling their story through the movement of words on the page. In the three-step process, I provide first a verbatim extract.

\section{Verbatim extract (Growing up)}

L: Yeah, ok, um so can you tell me a little about your um life experience, your childhood, about grow, things about growing-up at Weilmoringle, some things you might've [might have] done an' [and]

$E$ : Yeah um the most um wonderful childhood I've [I have] known out there its jist [Just] so free

\section{$L: \mathrm{Mm}$}

$E$ : That there was no not like what's goin' [going] on today there was no alcohol or drugs an' stuff like that

$L: \mathrm{Mm}$

E: We had arh go an' make our own fun

$L: \mathrm{Mm}$

$E$ : Yeah see um go for walks all day in arh or on the weekends we use-tah [used to] go lookin' [looking] for gum go walkin' [walking] lookin' [looking] for gum $\mathrm{an}^{\prime}$ other times we'd [we would] go swimmin' [swimming] down at the bighole an-an' other times we'd-we'd make um instruments up um like guitars with um have a-have a bottle an' arh break the top off it

$L:$ Do ...

E: Take off a??? (unsure of words) an' stick yah [your] thumb in it

L: Yeah

$E$ : An' knock it onto the other bottle for a guitar

L: Yeah

$E$ : An' so we use-tah have some tins an-an' sticks an' for drums an' we'd have a concert each individual um person ad-tah [had to] get up an' sing their own song and do actions

L: Yeah 
$E$ : An' yeah it was a wonderful time out there at Weilmoringle...$^{36}$

The second step is the unedited free verse created from the verbatim transcript. In this example I have not added or rearranged any words. That is, all the 'ums' and 'arhs' are included. Punctuation is only used here when sentences are otherwise difficult to understand, but all effort is made to 'preserve the texture of the speech' ${ }^{37}$

\section{Unedited free verse (Growing up)}

Yeah um the most wonderful childhood I've known

out there

its jist so free

There was no

not like what's goin' on today

there was no alcohol or drugs an' stuff like that

We had-arh go an' make our own fun

Yeah see um

go for walks all day in arh

Or on the weekends we use-tah go lookin' for gum

go walkin'

lookin' for gum

An other times we'd go swimmin'

down at the bighole

An-an' other times we'd-we'd make um

instruments up um like guitars

with um have a

have a bottle

an' arh break the top off it

Take off a...

$\mathrm{an}^{\prime}$ stick yah thumb in it

An' knock it on to the other bottle for a guitar

$\mathrm{An}^{\prime}$ so we use-tah have some tins an-an' sticks an' for drums

$\mathrm{An}^{\prime}$ we'd have a concert

Each individual um person 'ad-tah get up

an' sing their own song an' do actions

$\mathrm{An}^{\prime}$ yeah it was a wonderful time out there

at Weilmoringle ...

In the final step, the edited free verse, I have made some minor editorial changes and omitted the false starts and repetitive words, the 'yeah', 'um' and 'arh'.

36 Elva Barker interviewed by Lorina Barker, 27 October 2005.

37 Samuel 1998: 391. 
With the participant's permission, this version would be included in the thesis, and if necessary their poem or story may undergo further editing: 'cutting, reorganizing and reshaping' to convey information during the presentation stage. ${ }^{38}$

\section{Edited free verse (Growing up)}

The most wonderful childhood I've known out there

Its jist so free

There was no...

Not like what's goin' on today

there was no alcohol or drugs an' stuff like that

We had-arh go an' make our own fun

go for walks all day

On the weekends we use-tah go lookin' for gum

we'd go swimmin'

down at the bighole

Other times we'd make instruments up like guitars

with a bottle

Break the top off it

$\mathrm{an}^{\prime}$ stick yah thumb in it

knock it on to the other bottle for a guitar

We use-tah have tins an' sticks for drums

an' we'd have a concert

each individual 'ad-tah get up

$a^{\prime}$ sing their own song an' do actions

It was a wonderful time out there

at Weilmoringle ...

\section{Example two: capturing the rhythm of speech}

Daphne Patai explains the structure of a poem: 'the shape of it and the breaks define our attitude and govern our reading. We have a different attitude to it than we would have if it was a newspaper article'.${ }^{39}$ Furniss and Bath also agree that the visual stimulus of a poem's layout 'alter[s] the way we read [it]'. ${ }^{40}$ Patai further explains that the 'ordinary spoken words, like written words, can be arranged so as to call attention to their poetic and expressive dimensions' ${ }^{41}$

38 Patai 1988: 17.

39 Quoted in Block 1995: 66.

40 Furniss and Bath 1996: 27.

41 Patai 1988: 20. 
Patai uses Dennis Tedlock's technique of 'following the pauses and inflections in the speaker's speech' when re-transcribing her informant's interviews. ${ }^{42}$ It is in the second example of free verse, that I have utilised both Patai's and Tedlock's suggestions to convey information, as I would do in prose. For example, personal background information: birth, marriages, the number of children; location of amenities: including houses, shower blocks; as well as details of events, dates and times. But unlike prose, I have chosen to include the participant's speech mannerisms to ensure that the reader hears the participant and not just a summary of their story. In the free verse I use line breaks, which indicate pauses or a change of topic and I use indentation to draw attention to the musical and poetical tone of the speaker's voice. The first step is the verbatim transcript followed by the unedited free verse and the third step is the edited free verse. What I have done in the extract 'Communal showers' is take what might be considered the everyday mundane details of a social environment and have presented them in a way that conveys the narrator's rhythm and tone of voice telling the story.

\section{Edited free verse (Communal showers)}

There was two parts of Weilmoringle

I don't know why?

But they called one en' top en'

$\mathrm{An}^{\prime}$ the other en' was the bottom en'

We use-tah live at the bottom en'

$\mathrm{An}^{\prime}$ the showers was situated

$\mathrm{Um}$

Behin' me Arnie Maggie's place

There was two showers one for the boys

$\mathrm{An}^{\prime}$ one for the girls

$\mathrm{An}^{\prime}$ in the middle they had wash-basins

Where yah wash clothes an' stuff

The first lotta runnin' water that we got on there

Clean water ...

\section{Example three: annotated free verse}

As mentioned earlier, my utilisation of free verse is to ensure that the research participants are able to easily understand and interpret their stories. However, in the process I also discovered, like Krista Woodley, that it was a "process to aid my analysis of the recording', ${ }^{43}$ particularly when identifying some of the common

42 Patai 1988: 19.

43 Woodley 2004: 49. 
themes of discussion and the participant's emphasis or avoidance of a topic. In the following example, I have incorporated Jane O'Sullivan's suggestions to show the pace of a person's speech by using the line breaks, indentation and the space on the page. As well as providing a code/key to indicate when a participant and the interviewer have laughed, by adding 'laugh' in brackets throughout the text. When a participant has raised his or her voice, BOLD CAPITAL letters are used to emphasise his or her boisterous response. The line breaks and indentation also signal when a person wanders off or changes topics and/or thought patterns. Step one is the verbatim transcript that is converted into the unedited free verse and the final step is the edited free verse as shown in the extract below.

\section{Edited free verse (First day of school)}

Yeah

I think

Very

Very first day

We 'adda bit of scene

Because at that time

I had my ole Arnie

Goin' tah school

Arnie Gwennie West

An' my first day [Drifting off, pulling herself back to the question]

See

Arnie Gwen took me tah school

Up at Weil we only had two

Two lines where yah git in-tah

Or four lines

Two for the senior kids

'an two for the junior kids

I was standin' [change of thought pattern]

Got in line real good

I lined up real great

But I didn't realise that my Arnie would go off

Because Weilmoringle school was jist

Two-roomed school

My Arnie went tah go one way

I had-tah go the other way

Outa the corner my eye

I caught 'er goin' the other way

So I took off runnin'

Grabbed hold to 'er arms 
I was goin' like that

Tah go with 'er

An' my teacher run tah git me see 'e draggin' me

Not draggin' me

'e was tryin' git me tah come back tah all the rest the little kids

I was coo-ee-in' sayin'

\section{"I WANNA GO WITH MY ARNIE"}

$\mathrm{An}^{\prime}$ 'e said

"No yah 'ave-tah come this other way"

I dunno, who was it

But someone walked past the school

An' seen it

They went home an' told Mum

The teacher was draggin' me

draggin' me aroun' [trail of thought

wandering off]

Mum come up there

For this young teacher

'cause 'e only was a young fulla

Chased him up one stairs

Down the other

Up the stairs an'

Down the other (laugh)

Then 'e

In the end

'e found the old principal

'e run behind

was hidin' behin' 'im

Mum was there coo-ee-in' at 'im

“YOU'D OR-TAH HIT MY BABY, LET ME HIT YOU" (laugh)

THAT WAS MY VERY FIRST DAY AT SCHOOL (laugh). ${ }^{44}$

\section{How will participants respond?}

Now that I have experimented with three different styles of free verse in an attempt to find my own unique approach it will be interesting to discover in follow-up sessions with participants their reactions to this method. How conducive was the use of free verse to each participant's understanding of their converted story? Was the text easier on the eye? To what extent do the methods

44 'Lois' (pseudonym) interviewed by Lorina Barker, 24 January 2006, transcript: 1-2. 
used reflect the voice and the individual? Do they echo their memories and history? It will also be interesting to find out the preferred method, as Brehaut discovered from her reviewers, a group of school children from the Hammersley Range, Western Australia who were uninterested in the 'polished and precise' version in prose and English, what Brehaut refers to as the 'tidy whitefella version' ${ }^{45}$ I acknowledge GS Fraser's point about some of the problems common to free verse, especially how the research participants may read or interpret their stories. He explains, 'free verse runs more risks than other kinds of English verse, in that it cannot give always such clear and definite clues as regular verse about how the poet would like one to read it aloud (or hear it... in one's head)'. ${ }^{46}$ Nevertheless, as Francis Good explained in his quotation of Barry York's argument for the utilisation of free verse poetry, 'sensitivity to the lyric aspects of speech can be a basis for presenting phrases or sentences in the manner of "verse libre ... poetry" which may bring us closer to aspects of the oral source'. ${ }^{47}$

In conclusion, while the transcript is an essential component of oral history research it is secondary to the recorded interview. The transcript's value lies in its accessibility to the intended audience. Although a verbatim transcript may be accessible to researchers and some participants who are familiar with the format and are able to analyse, interpret and deduce meaning from the material, it is not the only form. Rather there are several different methods that can be employed to make the transcript more accessible to Aboriginal people, such as free verse. However, how successful this approach is, in making the transcript accessible, will be determined by the research participants. Will they understand and obtain meaning from the transcript? More importantly, are they of the opinion that it reflects their stories and speech mannerisms?

The written record as poetry, like art, music and dance, is yet another way of capturing and transmitting cultural knowledge and people's lived experiences. But before we can record myth, memories and Indigenous histories, as researchers it is crucial that we consider how this can be culturally, sensitively and ethically achieved. As demonstrated in this paper, it can be accomplished through the consultation and interviewing processes and the recording, transcribing and presentation stages. Thus, as a transcription and translation technique, free poetic verse not only makes the research material readily available, it also provides our families and communities with a degree of ownership of their cultural knowledge and history. 


\section{References}

Brehaut, Loreen 1999, 'A terrible responsibility: editing the spoken word for print', Oral History Association of Australia Journal 21: 27-31.

Block, Rosemary 1995, 'Voiceprint: from tape to page: keeping faith with the voice', Oral History Association of Australia Journal 17: 65-73.

- 1997, 'Comments on Kate Moore's “Perversion of the word: the role of transcripts in oral history"', Words of Silence, Bulletin of the International Oral History Association 1(1): 32-35.

Eades, Diana 1996, 'Audiocassette 3, Band 2 Aboriginal English and Band 4 Aboriginal Data', in The English Language: Past, Present and Future Study Guide 3, The Open University, Rochester: 28-33.

Fraser, George Sutherland 1970, Metre, Rhyme and Free Verse, JD Jump (gen ed), Methuen \& Co Ltd, London.

Furniss, Tom and Michael Bath 1996, Reading Poetry: An Introduction, Pearson Education Limited, Harlow.

Good, Francis 2000, 'Voice, ear and text: words and meaning', Oral History Association of Australia Journal 22: 102-109.

Huggins, Jackie 1995, 'The theory, the practice and the frustrations', Women Writing: Views and Prospects 1975-1995 Seminar, National Library of Australia, Canberra, accessed 25 September 2009: <http://www.nla.gov.au/ events/huggins.html>

Jones, Rebecca 2004, 'Blended voices: crafting a narrative from oral history interviews', The Oral History Review 31(1): 23-42.

Lowenstein, Wendy 1992, 'You just don't ask questions like that!', Oral History Association of Australia Journal 14: 40-43.

Moore, Kate 1997, 'Perversion of the word: the role of transcripts in oral history', Words of Silence Bulletin of the International Oral History Association 1(1): $14-25$.

Patai, Daphne 1988, Brazilian Women Speak: Contemporary Life Stories, Rutgers University Press, New Brunswick.

Perry, Katharine Elise 2005, 'Tales full of music and strong and resourceful women: one woman's memories of a childhood spent in rural Queensland during the Depression', Oral History Association of Australia Journal 27: 1-7. 
Passionate Histories

Samuel, Raphael 1998, 'Perils of the transcript', in The Oral History Reader, R Perks and A Thomson (eds), Routledge, London: 389-392.

Woodley, Krista 2004, 'Let the data sing: representing discourse in poetic form', The Journal of the Oral History Society 32(1): 49-58.

Wright, Elizabeth A 2005, 'Tales from the "scripts"”, Oral History Association of Australia Journal 27: 56-62. 